\title{
Pengaruh jenis asam dan temperatur ekstraksi terhadap yield dan karakteristik pektin dari kulit pisang kepok
}

\author{
The effect of solvent and temperature on yield and pectin characteristics from kepok banana \\ peels
}

\author{
Yuli Ristianingsih*, Indriana Lestari, Wibiana Wulan Nandari
}

\begin{abstract}
Program Studi Teknik Kimia, Jurusan Teknik Kimia, Fakultas Teknik Industri, Universitas Pembangunan Nasional Veteran Yogyakarta, Jl. SWK 104 (Lingkar Utara) Condong Catur, Yogyakarta 55283, Indonesia
\end{abstract}

\section{Artikel histori :}

Diterima 08 Agustus 2021

Diterima dalam revisi 02 Oktober 2021

Diterima 10 Oktober 2021

Online 1 November 2021

\begin{abstract}
ABSTRAK: Pektin merupakan senyawa polisakarida yang melapisi dinding sel tanaman. Pektin banyak dimanfaatkan sebagai zat perekat dan pengental pada industri makanan, farmasi dan juga sebagai adsorben pada pengolahan limbah. Penelitian ini menggunakan kulit pisang kepok sebagai bahan baku. Tujuan penelitian ini adalah mempelajari pengaruh temperatur dan jenis pelarut (asam asetat dan $\mathrm{HCl}$ ) terhadap karakteristik pektin (kadar abu. Kadar metoksil dan galakturonat). Penelitian dilakukan dalam sebuah reaktor berpengaduk selama 90 menit dengan variasi jenis pelarut ( $\mathrm{HCl}$ dan asam asetat) dan temperatur ekstraksi (60, 70, 80 dan 90) ${ }^{0} \mathrm{C}$. berdasarkan penelitian diperoleh rendemen maksimal dihasilkan pada pektin dengan pelarut $\mathrm{HCl} 0,25 \mathrm{~N}$ pada temperatur $80^{\circ} \mathrm{C}$ sebesar $24,93 \%$. Karakteristik pektin yang meliputi kadar galakturonat, kadar metoksil, kadar abu dan berat ekivalen pada temperatur ekstraksi $80^{\circ} \mathrm{C}$ dengan konsentrasi $\mathrm{HCl} 0,25 \mathrm{~N}$ masing-masing adalah 79,56\%; 2,65; 6,72\% dan 3846 .
\end{abstract}

Kata Kunci: kulit pisang kepok; pektin; asam klorida; asam asetat

ABSTRACT: Pectin is structurally and functionally the most complex polysaccharide in plant cell walls. Pectin is widely used as an adhesive and emulsifier in the food, pharmaceutical industry and also as an adsorbent in waste water treatment. This research used banana peels as a raw material. The purpose of this study was to study the effect of temperature and solvent (acetic acid and hydrochloric acid) on the characteristics of pectin (ash content, methoxyl and galacturonic content). This research was carried out in a stirred tank reactor for 90 minutes with various types of solvents (hydrochloric acid and acetic acid) and extraction temperatures $(60,70,80$ and 90$){ }^{\circ} \mathrm{C}$. Based on the research, it was found that the optimum pectin yield with $0.25 \mathrm{~N} \mathrm{HCl}$ at a temperature of $80^{\circ} \mathrm{C}$ was $24.93 \%$. The characteristics of pectin which include galacturonic acid, methoxyl content, ash content and equivalent weight at an extraction temperature of $80^{\circ} \mathrm{C}$ with a concentration of $0.25 \mathrm{~N} \mathrm{HCl}$ were $79,56 \% ; 2.65 ; 6,72 \%$ and 3846 .

Keywords: banana peels, pectin, hydrochloric acid, acetic acid

\section{Pendahuluan (Introduction)}

Pisang (Musaceaea sp) merupakan salah satu buah yang banyak ditemui di Indonesia dan banyak diolah menjadi berbagai makanan mulai dari roti, snack kering, dan berbagai produk olahan pangan lainnya. Pemanfaatan pisang sebagai produk olahan makanan menghasilkan kulit pisang yang dapat mencemari lingkungan. Kulit pisang selama ini hanya digunakan sebagai makanan ternak dan bahkan sebagian besar hanya dibuang sebagai sampah. Padahal pada kulit pisang mengandung senyawa pektin yang cukup besar sekitar 22,4\% (Megawati dan Elfi, 2016).

\footnotetext{
* Corresponding author:

Email: y.ristianingsih@upnyk.ac.id
}

Pektin merupakan polisakarida kompleks yang bersifat asam dan tersebar secara merata dalam jaringan tanaman. Di dalam sel tanaman, pektin berfungsi sebagai perekat dinding sel satu dengan dinding sel lainnya (Winarno, 1997). Pektin termasuk dalam golongan polisakarida yang larut dalam air. Pektin banyak dimanfaatkan dalam industri makanan dan farmasi. Dalam industri makanan, pektin digunakan sebagai bahan pengemulsi dan penstabil produk-produk makanan. Sedangkan pada bidang farmasi, pektin banyak digunakan sebagai pengental dan campuran obat (Akhmalludin, 2011). Kebutuhan pektin untuk berbagai industri di Indonesia banyak diperoleh dari impor karena masih 
sangat sedikit industri di Indonesia yang menghasilkan pektin. Menurut Badan Pusat Statistik, 2012 di dalam Injilauddin dkk, (2015), nilai impor pektin pada tahun 2011 mencapai $291.870 \mathrm{~kg}$. Untuk mengurangi tingkat impor pektin di Indonesia maka diperlukan penelitian lebih lanjut tentang proses produksi pektin dari berbagai jenis tanaman yang ada di Indonesia.

Proses ekstraksi pektin terdiri dari empat tahapan proses yang meliputi proses ekstraksi, pemurnian, pengendapan dan pengeringan. Pada umumnya, ekstraksi pektin menggunakan pelarut asam seperti asam klorida, asam sulfat, asam asetat, asam sitrat, dll (Vina, 2003).

Penelitian yang berhubungan dengan proses ekstraksi pektin dari berbagai jenis bahan baku sudah banyak dilakukan oleh peneliti sebelumnya. Selain menggunakan jenis bahan baku yang beraneka ragam, pengolahan pektin juga menggunakan berbagai jenis pelarut dan variabel penelitian yang berbeda-beda (temperatur, $\mathrm{pH}$, konsnetrasi pelarut dll). Bahan baku pembuatan pektin yang sudah pernah dilakukan pada penelitian sebelumnya banyak memanfaatkan limbah kulit buah seperti kulit buah sukun (Budi hermanto dkk, 2017), kulit lemon (Kesuma dkk, 2018), kulit cempedak (Nurhaeni, dkk., 2018), kulit pisang kapok (Megawati dan Elfi, 2016), kulit jeruk manis (Jolantje dkk., 2019) dll. Berdasarkan penelitian Injilauddin dkk (2015), Nurviani dkk. (2014), Margani (2012) dan Arviani (2009) proses ekstraksi pektin dipengaruhi oleh tiga faktor utama yaitu temperatur, jenis dan konsentrasi pelarut, $\mathrm{pH}$ dan waktu ekstraksi. Semakin tinggi temperatur ekstraksi maka proses reaksi pembentukan pektin akan semakin cepat begitu sebaliknya. Kekuatan asam sangat berpengaruh terhadap proses hidrolisis protopektin menjadi pektin sehingga akan mempengaruhi karakteristik dari pektin yang dihasilkan (Rachmawan dkk., 2005). Selain jenis pelarut, konsentrasi pelarut juga mempengaruhi proses ekstraksi pektin. Semakin tinggi konsentrasi asam yang digunakan maka akan mempercepat proses degradasi pektin menjadi asam pektat (Tuhuloula dkk, 2013).

Berdasarkan penelitian sebelum tentang pembuatan pektin berbahan baku kulit pisang (Hanum dkk, 2012a; Tuhuloula dkk, 2013; Megawati dkk, 2016 dan Nurhayati $\mathrm{dkk}, 2016)$ sebagian besar peneliti hanya menggunakan satu jenis pelarut yaitu $\mathrm{HCl}$ pada proses ekstraksi pektinnya. Penelitian ini memproduksi pektin dari limbah kulit pisang dengan mempelajari jenis pelarut $(\mathrm{HCl}$ dan asam asetat) untuk mengetahui jenis pelarut terbaik pada proses ekstraksi pektin. Selain itu, pada penelitian ini juga mempelajari pengaruh konsentrasi pelarut dan temperatur reaksi. Berbagai variabel proses yang dipelajari dimaksudkan untuk mengetahui kondisi optimum proses agar memperoleh rendemen pektin yang maksimal serta pengaruh variabel proses terebut terhadap karakteristik pektin yang dihasilkan seperti kandungan metoksil, kandungan asam galakturonat, kadar abu dan berat ekivalen.

\section{Metode penelitian}

\subsection{Alat dan bahan}

Bahan baku pembuatan pektin pada penelitian ini adalah kulit pisang kepok yang didapat dari restoran Kopi Klothok daerah Yogyakarta dan pedagang gorengan di sekitar Yogyakarta. Bahan kimia yang digunakan pada penelitian ini adalah alkohol $96 \%$ (teknis), asam klorida $37 \%$ (PA), asam asetat 99\% (PA), aquades, Indikator phenolphtalein, phenol red dan natrium hidroksida $(\mathrm{NaOH})$ 99\% (PA).

Penelitian ini dilakukan pada rangkaian alat ekstraksi yang terdiri dari labu leher tiga, kondensor, pengaduk magnetic, kompor magnetik stirrer serta termometer.

\subsection{Prosedur percobaan}

Sebanyak $20 \mathrm{~g}$ kulit pisang dibersihkan dipotong kecilkecil dan dikeringkan di bawah sinar matahari selama tiga hari. Hal ini bertujuan untuk mengurangi kandungan air dari bahan baku. Setelah kering, kulit pisang tersebut kemudian dihaluskan menggunakan blender dan dikeringkan menggunakan oven pada temperatur $35{ }^{0} \mathrm{C}$ selama 8 jam hingga didapatkan serbuk kulit pisang kering. Serbuk kulit pisang kering ini kemudian diekstraksi selama 90 menit dengan pengadukan $300 \mathrm{rpm}$. Variabel yang dipelajari pada proses ekstraksi ini adalah jenis pelarut yang terdiri dari pelarut $\mathrm{HCl}$ dan asam asetat, konsentrasi pelarut $(0,2 ; 0,25 ; 0,3$ dan $0,35 \mathrm{~N})$ dan temperatur reaksi $(60,70,80$ dan 90$){ }^{\circ} \mathrm{C}$. Pektin yang dihasilkan pada proses ekstraksi adalah pektin masam. Pektin masam kemudian di cuci dengan menggunakan alkohol $96 \%$ sampai $\mathrm{pH}$ netral dengan ratio $1: 1$. Hal ini bertujuan untuk menghilangkan pelarut yang masih tersisa di dalam pektin. Setelah dicuci, kemudian larutan pektin diendapkan selama 12 jam untuk memisahkan pektin dengan pelarut (alkohol 96\%). Setelah terbentuk dua lapisan (lapisan pelarut dan endapan pektin) kemudian endapan pektin disaring menggunakan kertas saring dan larutan filtrat ditampung. Endapan pektin yang diperoleh berupa pektin basah yang kemudain akan dikurangi kandungan airnya menggunakan oven pada temperatur $35{ }^{\circ} \mathrm{C}$ selama 2 jam sehingga diperoleh pektin kering. Pektin kering ini kemudian ditumbuk dan diayak pada ukuran 60 mesh. Setelah itu bubuk pektin kering ditimbang untuk mengetahui berat pektin yang dihasilkan serta dilakukan analisis karakteristik pektin yang meliputi analisis kadar metoksil, kadar galakturonat, kadar abu dan berat ekivalen pektin.

\subsection{Analisis karakteristik pektin \\ 2.3.1. Analisis berat ekivalen}

Analisa berat ekivalen pada penelitian menggunakan metode titrasi (Ranganna, 1977). Sejumlah 0,5 g pektin dimasukkan ke dalam gelas beker $250 \mathrm{ml}$ kemudian dilautkan dengan $100 \mathrm{ml}$ aquades bebas $\mathrm{CO}_{2}$. Larutan pektin yang diperoleh ditambahkan 6 tetes indikator phenol red dan dititrasi menggunakan larutan $\mathrm{NaOH} 0,1 \mathrm{~N}$ hingga berubah warna menjadi merah muda. Catat volume $\mathrm{NaOH}$ yang digunakan untuk titrasi sebagai $\mathrm{ml} \mathrm{NaOH}$ (V1). Berat ekivalen kemudian dicari dengan menggunakan persamaan berikut: 
berat ekivalen $(g / e k i)=\frac{\text { berat contoh }(g) \times 1000}{m l \mathrm{NaOH} \times \mathrm{N} \mathrm{NaOH}}$

\subsubsection{Analisis kadar metoksil}

Larutan hasil analisa berat ekuivalen dimasukkan ke dalam gelas beker dan ditambahkan $0,25 \mathrm{~N}$ natrium hidroksida sebanyak $25 \mathrm{ml}$. larutan tersebut kemudian dikocok/ diaduk sampai homogen dan biarkan sampai 30 menit pada temperatur kamar. Setelah 30 menit, tambahkan $0,25 \mathrm{~N}$ asam klorida sebanyak $25 \mathrm{ml}$ dan indikator phenolphthalein kemudian dititrasi menggunakan natrium hidroksida $0,1 \mathrm{~N}$ hingga berubah warna menjadi merah muda. Catat volume $\mathrm{NaOH}$ yang digunakan sebagai titrasi sebagai $\mathrm{ml} \mathrm{NaOH}$ (V2). Kadar metoksil pektin dicari dengan menggunakan persamaan (Ranganna, 1977) berikut:

$$
\text { kadar metoksil }(\%)=\frac{m l \mathrm{NaOH} \times \mathrm{N} \mathrm{NaOH} \times 3,1}{\text { berat contoh }(g)}
$$

\subsubsection{Analisis kadar galakturonat}

Analisis kadar galakturonat dilakukan dihitung dengan menggunakan persamaan (Ranganna, 1977):

Asam galakturonat $(\%)=\frac{176(A+B+C)}{\text { berat contoh }(\mathrm{mg})} \times 100$

Dengan nilai:

$\mathrm{A}=$ miliekuivalen $\mathrm{NaOH}$ yang digunakan dalam analisa berat ekuivalen;

$\mathrm{B}=$ miliekuivalen $\mathrm{NaOH}$ yang diperlukan pada analisa kadar metoksil

$\mathrm{C}=$ miliekuivalen $\mathrm{NaOH}$ yang digunakan untuk penetapan alkalinitas abu.

\subsubsection{Penentuan alkalinitas abu}

Penentuan alkalinitas abu pada penelitian ini dilakukan dengan melarutkan abu yang diperoleh dari pengabuan $1 \mathrm{~g}$ contoh dalam $25 \mathrm{ml} \mathrm{HCl} 0,1 \mathrm{~N}$. Larutan selanjutnya dipanaskan sampai mendidih. Setelah dingin, larutan ditetesi indikator phenolphthalein lalu dititrasi dengan $\mathrm{NaOH} 0,1 \mathrm{~N}$ sampai berubah warna menjadi merah muda.

\section{Hasil dan pembahasan}

\subsection{Rendemen pektin pada berbagai temperatur dan}

\section{konsentrasi pelarut}

Temperatur pada proses ekstraksi akan mempengaruhi ikatan antar molekul protopektin (Budi Hermanto dkk, 2017). Temperatur berbanding lurus dengan yield pektin yang dihasilkan. Temperatur yang semakin tinggi akan menghasilkan rendemen pektin yang tinggi begitupun sebaliknya. Semakin tinggi temperatur akan meningkatkan tumbukan antar molekul sehingga proses hidrolisis protopektin akan semakin meningkat (Hariyati, 2006).

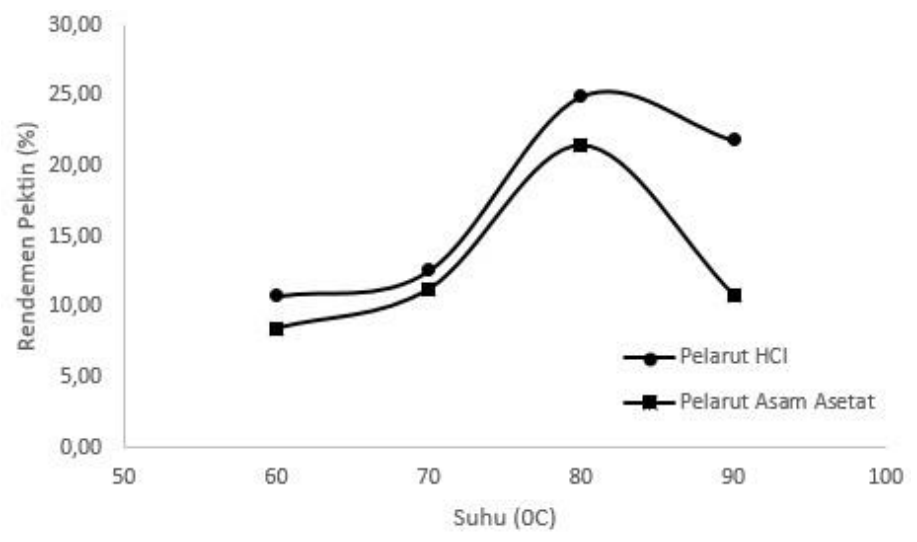

Gambar 1. Pengaruh Temperatur Reaksi Terhadap Rendemen Pektin

Kenaikan temperatur akan berpengaruh terhadap mobilitas zat pelarut dimana dengan meningkatnya temperatur maka proses ekstraksi akan berlangsung lebih cepat dengan hasil pektin yang lebih banyak. Akan tetapi temperature yang terlalu tinggi akan mengakibatkan ikatan hydrolytic pada ikatan galakturonat menjadi cepat terlepas dan mengakibatkan senyawa pektin menjadi rusak. Hubungan antara temperatur ekstraski dan nilai rendemen pektin pada penelitian ini dapat dilihat pada Gambar 1.

Gambar 1 menunjukkan bahwa rendemen tertinggi dihasilkan pada temperatur $80{ }^{\circ} \mathrm{C}$ untuk pelarut $\mathrm{HCl}$ dan asam asetat masing-masing sebesar $24,93 \%$ dan $21,49 \%$. Ekstraski pektin dilakukan dengan cara menghidrolisis protopektin menjadi pektin dengan menggunakan pelarut asam. Konsentrasi pelarut sangat mempengaruhi rendemen pektin yang dihasilkan seperti yang terlihat pada Gambar 2 berikut:

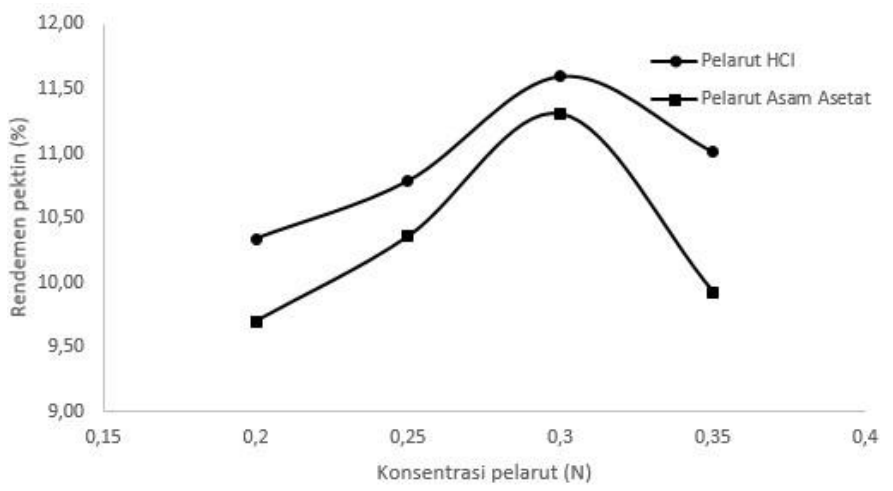

Gambar 2. Pengaruh Konsentrasi Pelarut Terhadap Rendemen Pektin

Konsentrasi pektin berbanding lurus dengen rendemen pektin yang dihaislkan. Semakin tinggi konsentrasi pektin maka semakin tinggi juga rendemen pektin yang diperoleh. Akan tetapi jika konsentrasi pektin terlalu besar akan mengakibatkan terjadinya degradasi/ penguraian pektin menjadi asam pektat yang membuat kadar pektin yang diperoleh mengalami penurunan. Rendemen pektin tertinggi diperoleh pada konsentrasi $0,3 \mathrm{~N}$ pada untuk jenis pelarut $\mathrm{HCl}$ dan asam asetat masing-masing sebesar 
$11,60 \%$ dan $11,31 \%$. \%. Pelarut $\mathrm{HCl}$ memberikan nilai rendemen pektin yang jauh lebih besar daripada asam asetat. Hal ini dikarenakan atom hidrogen pada gugus karboksilat $(-\mathrm{COOH})$ dalam asam karboksilat seperti asam asetat dapat dilepaskan sebagai ion $\mathrm{H}^{+}$(proton), sehingga memberikan sifat asam. Asam asetat merupakan asam lemah monoprotik dengan nilai $\mathrm{pKa}=4,8$. Sedangkan $\mathrm{HCl}$ merupakan asam kuat yang memiliki nilai asam lebih tinggi jika dibandingkan dengan asam asetat (Susanti dkk., 2015). Asam klorida merupakan jenis asam kuat yang memiliki nilai tetapan kesetimbangan (K) yang lebih besar jika dibandingkan asam asetat yang merupakan asam organik lemah (Hesti, 2003). Nilai tetapan kesetimbangan untuk asam klorida sebesar $10^{7}$ sedangkan nilai tetapan kesetimbangan untuk asam asetat sebesar 7,21 x10 4 . Nilai K yang besar akan meningkatkan kekuatan suatu asam dalam menarik ion divalent dan menggantinya dengan ion hidrogen. Ion hidrogen berperan penting dalam proses hidrolisis protopektin menjadi pektin sehingga akan memperoleh rendemen pektin yang tinggi (Kesuma dkk, 2018).

\subsection{Karakteristik pektin Berat ekivalen}

Berat ekivalen merupakan ukuran terhadap kandungan gugus asam galakturonat bebas (tidak teresterifikasi) dalam rantai molekul pektin. Semakin tinggi kadar pektin maka nilai berat ekivalen akan semakin tinggi begitupun sebaliknya (Hanum dkk, 2012a). Berat ekivalen pektin hasil penelitian berkisar antara 2040-2631 mg. Nilai ini tidak sesuai dengan standar IPPA (International Pectin Producers Association ) dengan nilai berat ekivalen anatar 600-800 mg. hal ini mungkin dipengaruhi oleh proses ekstraski yang dilakukan serta sifat pektin hasil ekstraski itu sendiri (Fitriani, 2003).

\section{Kadar metoksil}

Kadar metoksil suatu pektin adalah banyaknya metanol yang terkandung di dalam pektin. Kandungan metoksil sangat berpengaruh terhadap tekstur dan struktur jel pektin yang terbentuk serta mempengaruhi sifat fungsional dari larutan pektin yang diperoleh (Budiyanto dan Yulianingsih, 2008).

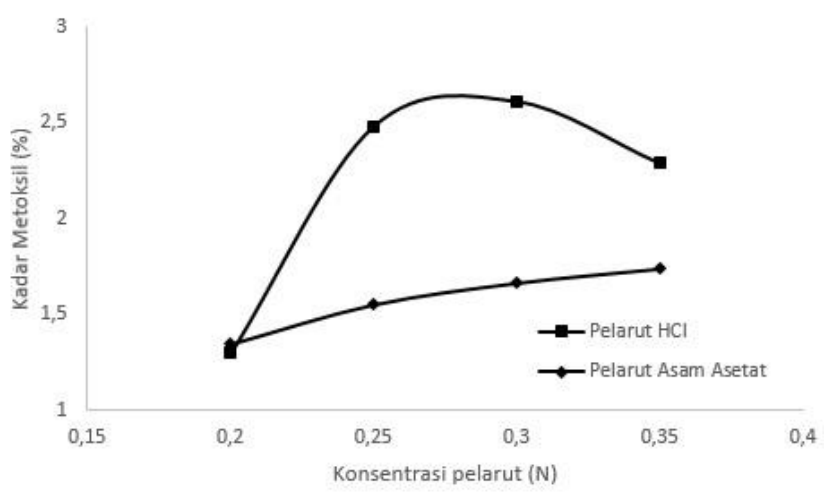

Gambar 3. Pengaruh Jenis dan Konsentrasi Pelarut Terhadap Kadar Metoksil
Pektin bermetoksil tinggi memiliki nilai kadar metoksil lebih dari 7\% dan jika kurang dari 7\% maka pektin tersebut tergolong bermetoksil rendah. Kadar metoksil pektin hasil penelitian berkisar antar 1,2 sampai 3,16\%.

Hal ini menunjukkan bahwa pektin hasil penelitian tergolong pektin yang bermetoksil rendah sesuai dengan standar IPPA dimana pektin yang bermetoksil tinggi mempunyai nilai pektin $>7,12 \%$ dan jika nilai pektin kurang dari 7,12 maka pektin tersebut tergolong dalam pektin bermetoksil rendah (Kesuma dkk, 2018). Kadar metoksil pektin dari berbagai konsentrasi pelarut dan jenis pelarut dapat dilihat pada Gambar 3.

Dari Gambar 3 dapat dilihat bahwa pelarut jenis $\mathrm{HCl}$ mempunyai kandungan metoksil yang jauh lebih tinggi jika dibandingkan dengan asam asetat karena asam asetat memiliki nilai $\mathrm{K}$ (konstanta kesetimbangan) yang jauh lebih kecil dibandingkan dengan $\mathrm{HCl}$. Nilai $\mathrm{K}$ yang lebih besar akan meningkatkan jumlah ion hidrogen untuk menghidrolisis protopektin menjadi pektin. Semakin banyak pektin yang dihaislkan maka jumlah metanol pada gugus karboksil teresterifikasi juga semakin meningkat dan mengakibatkan nilai metoksi menjadi lebih tinggi (Hanum, 2012b).

\section{Kadar galakturonat}

Asam poligalakturonat adalah kerangka dasar senyawa pektin yang menggambarkan kemurnian pektin. Tingginya kadar galakturonat suatu pektin menandakan bahwa pektin yang dihasilkan semakin murni dan memiliki kandungan pengotor/ zat organik (arabinose, galaktosa, ramnosa, dll) semakin sedikit. Selain itu kandungan poligalakturonat suatu pektin sangat mempengaruhi pembentukan gel. Semakin banyak kadar galakturonat pektin maka gel yang terbentuk akan semakin kuat dan tidak mudah terlepas. Kandungan asam galakturonat bervariasi antara 30-95\%. Kandungan galakturonat dalam pektin hasil penelitian dapat dilihat pada Gambar 4. berikut:

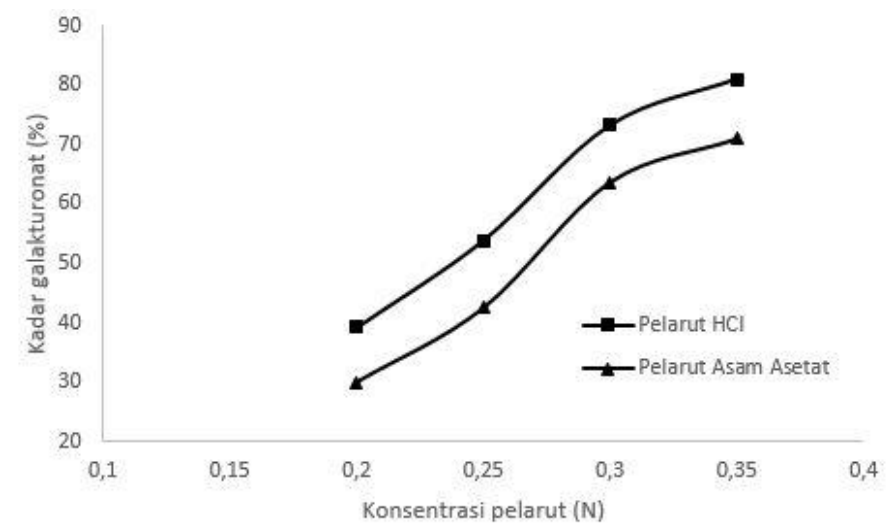

Gambar 4. Pengaruh Jenis dan Konsentrasi Pelarut Terhadap Kadar Galakturonat

Gambar 4 memperlihatkan kadar galakturonat pektin hasil penelitian dengan variasi jenis dan konsentrasi pelarut. Kadar galakturonat pektin dari kulit pisang kapok berkisar antara 30,05-81,04\%. Kadar galakturonat tertinggi diperoleh dari pektin dengan pelarut asam klorida 
konsentrasi $0,35 \mathrm{~N}$ sebesar $81,04 \%$. Nilai galakturonat ini tergolong cukup tinggi. Hal ini menandakan bahwa kemurnian dari pektin cukup besar sehingga gel yang terbentuk cukup baik dan kuat.

\section{Kadar abu}

Abu merupakan sisa pembakaran bahan organic yang berupa bahan anorganik. Kadar abu ini sangat mempengaruhi tingkat kemurnian pektin (Agus dan Yulianingsih, 2008). Pektin yang baik memiliki kandungan kadar abu yang rendah. Analisis kadar abu digunakan untuk mengetahui spesifikasi mutu kering suatu pektin. Kadar abu yang terkandung dalam suatu pektin dipengaruhi oleh adanya residu bahan baku, metode ekstraksi serta isolasi pektin. Kadar abu pektin berbahan baku kulit pisang kepok berkisar antara 1,27-8,56\%. Nilai ini sesuai dengan standar mutu pektin berdasarkan IPPA (International Pectin Producers Association ) yaitu maksimal $10 \%$.

\section{Kesimpulan (Conclusion)}

Berdasarkan hasil dan pembahasan dapat diambil kesimpulan sebagai berikut:

1. Temperatur ekstraksi sangat mempengaruhi rendemen pektin yang diperoleh. Semakin tinggi temperatur maka semakin besar rendemen pektin yang diperoleh. Akan tetapi jika temperatur terlalu tinggi akan mengakibatkan pektin menjadi rusak. Rendemen pektin tertinggi diperoleh pada temperatur $80{ }^{\circ} \mathrm{C}$ dengan menggunakan pelarut $\mathrm{HCl}$ sebesar $24,93 \%$.

2. Semakin tinggi konsentrasi pektin maka rendemen pektin yang dihasilkan akan semakin besar. Nilai rendemen tertinggi diperoleh pada konsentrasi $\mathrm{HCl}$ $0,3 \mathrm{n}$ dengan rendemen pektin sebesar $11,60 \%$.

3. Pelarut $\mathrm{HCl}$ menghasilkan rendemen pektin yang jauh lebih besar jika dibandingkan dengan pelarut asam asetat.

4. Pektin hasil penelitian termasuk kedalam pektin dengan kadar metoksil rendah karena memiliki kadar metoksil berkisar 1,2-3,16\%. Berdasarkan kadar galakturonat, pektin yang dihasilkan memiliki kemurnian yang tinggi karena memiliki nilai galakturonat maksimum $81,04 \%$. Kadar abu pektin hasil penelitian sudah sesuai dengan standar IPPA yaitu berkisar antara $1,27-8,56 \%$. Berat ekivalen pektin hasil penelitian masih dibawah standar IPPA yaitu berkisar antara 2040-2631 mg.

\section{Ucapan Terima kasih (Acknowledgments)}

Penulis mengucapkan terimakasih kepada Lembaga Penelitian dan Pengabdian Masyarakat (LPPM) Universitas Pembangunan Nasional "Veteran" Yogyakarta yang telah mendanai penelitian ini melalui dana hibah penelitian dasar 2021.

\section{Daftar Pustaka}

Akhmalludin A. K., 2011, Pembuatan pektin dari kulit coklat dengan cara ekstraksi, Skripsi. Semarang: Jurusan Teknik Kimia. Fakultas Teknik. Universitas Diponegoro Tembalang.

Arviani, 2009, studi perbandingan metode ekstraksi pektin pada kulit jeruk (Citrus Sp), Skripsi. Palu: Prog Studi Kimia. Fakultas MIPA. Universitas Tadulako.

Budi H., Nurhaeni, Ruslan, 2017, Optimalisasi ekstraksi pektin dari kulit buah sukun (Artocarpus altilis). Kovalen Vol 3 No 2., Agustus: 158-165

Budiyanto, A. dan Yulianingsih, 2008, Pengaruh temperatur dan waktu ekstraksi terhadap karakter pektin dari ampas jeruk siam (Citrus nobilis L). Jurnal Pascapanen. Vol.5 No 2, Juni: 37-44.

Fitriani, V. 2003. Ekstraksi dan karakteristik pektin dari kulit jeruk lemon (Citrus medica var Lemon). Skripsi. Bogor: Fakultas Teknologi Pertanian IPB

Hanum, F., Tarigan M.A., Kaban I.M.D., 2012a, Ekstraksi pektin dari kulit buah pisang kapok, Jurnal Teknik Kimia USU Vol 1 No 1, Maret: 49-53

Hanum F., Kaban I.M.D., Tarigan M.A., 2012b, Ekstraksi pektin dari kulit buah pisang raja (Musa sapientum), Jurnal Teknik Kimia USU Vol 1 No2, September: 21-26.

Hariyati M. N., 2006, Ekstraksi dan karakteristik pektin dari limbah proses pengolahan jeruk pontianak (Citrus nobilis var mierocarpa). Skripsi. Bogor: Fakultas Teknologi Pertanian Institut Pertanian Bogor.

Hesti, M. dan I. Sailah, 2003, Produksi pektin dari kulit jeruk lemon (Citrus medica), Prosiding Simposium Nasional Polimer 5, Hal: 117-126

Injilauddin A. S., Lutfi M., Nugroho A. W., 2015, Pengaruh temperatur dan waktu pada proses ekstraksi pektin dari kulit buah nangka (Artocarpus heterrophyllus), Jurnal Keteknikan Pertanian Tropis dan Biosistem Vol 3 No 3, Oktober: 280-286

Jolantje L, Fransina E.G., Tanasale M., Batawi C.Y., 2019, Ekstraksi dan karakterisasi pektin kulit jeruk manis kisar (Citrus sp), Indo. J.Chem. Res. Vol 7 No 1, Juli: 61-68

Kesuma N.K.Y., Widarta, I.W.R., Permana, 2018, Pengaruh jenis asam dan $\mathrm{pH}$ pelarut terhadap karakteristik pektin dari kulit lemon (Citrus limon), Jurnal Ilmu dan Teknologi pangan Vol 7 No 4., Desember: 192-203

Megawati, Elfi Lutfiyatul M, 2016, Ekstraksi pektin dari kulit pisang kepok (Musa paradisiaca) menggunakan pelarut $\mathrm{HCl}$ sebagai edible film, Jurnal Bahan Alam Terbarukan Vol 5 No 1, Juni: 14-21

Nurhaeni, Nur A.A., Jaya Hardi, Diharnaini, Khairunnisa, 2018, Ekstraksi dan karakterisasi pektin dari kulit dan dami buah cempedak (Artocarpus chempeden), Kovalen Vol 4 No 3, Desember: 304-315

Nurhayati N, Maryanto M, Tafrikhah R, 2016, Ekstraksi pektin dari kulit dan tandan pisang dengan variasi suhu 
dan metode, AGRITECH, Vol 36 No 3, Agustus: 327334

Nurviani, 2014, Ekstraksi dan karakterisasi pektin kulit buah pepaya (Carica papaya L.) dari beberapa varietas, Skripsi, Palu: Prog Studi Kimia. Fakultas MIPA. Universitas Tadulako.

Rachmawan, A., Lestari D., Dwierra E., dan Djoko S., 2005, Ekstraksi dan karakteristik pektin dari kulit buah kakao, Jurnal Ilmiah Pertanian Gakuryoku Vol 11 No 2, Juni: 190-194

Ranganna, S., 1977, Manual of analysis of fruit and vegetable products, New Delhi: Mcgraw Hill Book

Susanti D., Firdaus K., Hanifa A.U., Caraka F.H.V., Hartati I., 2015, Pelarut terbaik dalam pembuatan pektin dari limbah albedo durian (Durio zibethinus murray) dengan menggunakan metode MAE (Microwave Assited
Extraction), Prosiding SNST ke-6 Fakultas Teknik Universitas Wahid Hasyim. Hal: 23-26

Tuhuloula A., Budiyarti L., Fitriana E., 2013, Karakterisasi pektin dengan memanfaatkan limbah kulit pisang menggunakan metode ekstraksi, Konversi Vol 2 No1., April: 21-27

Winarno, F.G., 1997, Kimia Pangan dan Gizi, PT Gedia Pustaka Utama, Jakarta.

Vina F, 2003, Ekstraksi dan karakteristik pektin dari kulit jeruk lemon (Citrus medica Var Lemon). Skripsi. Bogor: Jurusan Teknologi Industri Pertanian IPB. 